the source of their originality. It contains a generous ration of the wonderful photographs taken by the Wright brothers of their gliding experiments, and forms an engaging account of these epochal events. However, those wanting more depth must go to the two authors' earlier books: Tom Crouch's The Bishop's Boys (W. W. Norton, 1989) and Peter Jakab's Visions of a Flying Machine (Smithsonian Institution Press, 1990).

The aviator and celebrity Alberto SantosDumont continues to puzzle and intrigue, but many details of his life have been obscure, his own book My Airships being one of the few sources of information. So Paul Hoffman's Wings of Madness is a much-needed and long-overdue account. It concentrates more on Santos Dumont's life than on the details of his flying machines. This fabulously rich Brazilian coffee tycoon settled in Paris and took his first free balloon flight with a professional balloonmaker in 1897, proving his scientific credentials by ascribing the extra effervescence of the champagne he took aloft to the high altitude. He soon progressed to small, light airships, initially using the remarkably light internal combustion engine developed for the De Dion-Bouton tricycle. SantosDumont became a popular figure as he dashed and sometimes crashed around Paris, often demonstrating remarkable control and mooring the craft outside his apartment on the Champs-Élysées.

By 1906, Santos-Dumont, stimulated by the move among French aeronauts to better what they had heard of the Wrights' flight, had built a heavier-than-air craft. The diminutive Santos-Dumont stood in the vehicle as it made a wallowing 240-metre flight in the Parc de Bagatelle. This public flight attracted media attention but the craft was barely under control and made no contribution to heavier-than-air flight.

When Wilbur Wright came to France in 1908 , Santos-Dumont seemed put out by the adulation that the American received, and began to show the beginnings of the depression and mental problems that would subsequently dog him. He became obsessed with new uses for aeroplanes. The final straw, which caused him to take his own life, was seeing the use of aeroplanes in the Brazilian revolution of 1932. His last recorded words are said to have been: "I never thought my invention would cause bloodshed between brothers. What have I done?"

Andrew Nahum is senior curator of the Aeronautical Collection at the Science Museum, Exhibition Road, London SW7 2UD, UK.

\section{A healthy draught of scepticism}

\section{Eight Preposterous Propositions: \\ From the Genetics of \\ Homosexuality to the Benefits of Global Warming \\ by Robert Ehrlich \\ Princeton University Press: 2003. 360 pp. \\ $\$ 27.95, £ 18.95$}

\section{Walter Gratzer}

A little way into Robert Ehrlich's assault on obfuscation and unreason, your appalled eye will light on a table which reveals that more than a quarter of the population of the United States believes in witches, $41 \%$ in possession by the devil, fully a half in extrasensory perception (ESP), and no less than $45 \%$ are in no doubt that extraterrestrial beings have been stalking the Earth. (The physicist Leo Szilard said so too, but added that they are called Hungarians.) Worse still, even among the beneficiaries of a college education, only $16.5 \%$ are prepared to concede that Homo sapiens is a product of evolution, unaided by the hand of God.

Such dense fog between the ears is invariably linked to an inability to grasp that improbable events are merely manifestations of the rules of chance, and not of divine intervention. Oscar Wilde understood this ingrained disorder of the human intellect: "Man can always believe the impossible, but man can never believe the improbable," he observed. Ehrlich has set himself the heroic task, concealed beneath

\title{
Let it snow
}

It is said that no two snowflakes are identical. Each contains about a billion billion water molecules, so the number of possible configurations is enormous. These photographs by Patricia Rasmussen are from The Snowflake: Winter's Secret Beauty by Kenneth Libbrecht (Voyageur Press, \$20).
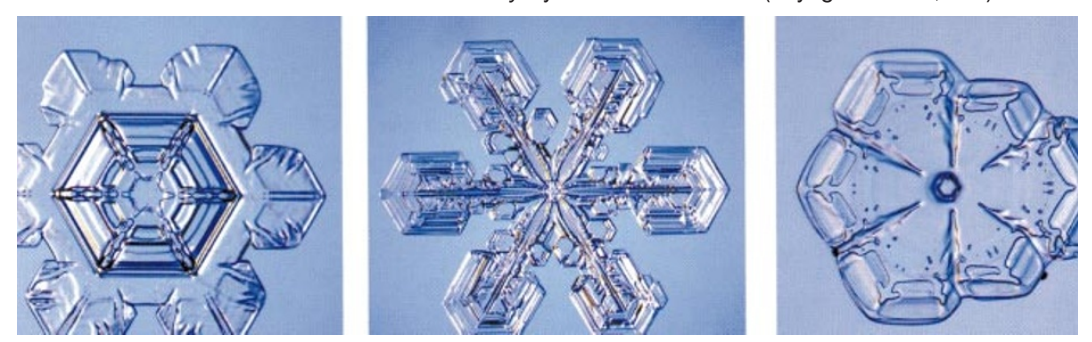

his flippant title, of confronting the tide of irrationality in what is in effect a manual of scientific reasoning.

His method, originating in his earlier book Nine Crazy Ideas in Science, is to test eight quite diverse propositions, extending from the unquestionably absurd (telekinesis, or moving matter around by thought alone) to the probably valid, such as a part for genetic factors in determining sexual inclination. He grades these on a scale of 'flakiness': zero flakes implies that the proposition may well be true, and four flakes that it is unarguably nonsense. My dictionary defines 'flaky' as "adj. eccentric, crazy", but this is not altogether what Ehrlich means by it; he conceives it as "lacking in empirical evidence or internal consistency", thereby distinguishing it from his 'crazy ideas' in science, some of which (like practically all of Kuhn's 'paradigm shifts') could be true.

Ehrlich's longest chapter is devoted to the weighty question: "Should you worry about global warming?” After an impeccably neutral analysis of the passionate opinions on either side, Ehrlich awards it a (judiciously qualified) 'one-flake' rating — in other words, a negative answer to the question could just about be entertained. A strength of Ehrlich's treatment is that he approaches the truly preposterous theses - telekinesis and the eclipse of evolution by "intelligent design" - with a straight face. His reasoned demolition of the evidence for these aberrations is vastly more effective than the red-eyed apoplexy that seizes the average scientist at their mere mention.

But it is the final two chapters that I found the most compelling. Ehrlich is at his most incisive on the placebo effect, and on the recent assertion in a widely publicized paper that its extent has been grossly exaggerated. The arguments hinge, for the most part, on the interpretation of statistics, which Ehrlich manages to make accessible to all who will make the effort. Only at one point, isolated in a box from which innumerate readers can avert their eyes, does he set out the mathematics in full.

He makes a powerful case that many, and especially psychotropic, drugs which make extravagant profits for the pharmaceutical industry are ineffective or worse. He uncovers the weaknesses in conventionally designed double-blind trials and, both here and in his final chapter ("Should you worry about your cholesterol?"), he expatiates on the lax standards by which the industry is now regulated, and the way in which the once-proud US Food and Drug Administration has been emasculated. What is especially striking is the low confidence limit $(P<0.05)$ considered adequate to establish the efficacy of a new drug in clinical trials - a level that is perhaps acceptable in sociological research, but is generally considered risible in the exact sciences. 
Ehrlich records the concern of one psychiatrist that if antidepressant drugs were shown to be ineffective, patients would suffer by being deprived of the benefits of the placebo effect. A striking study, published last year, revealed that in PET scans the same region in the brains of patients became active whether they were given placebos or opioid-receptor drugs. What we clearly need, then, are better placebos.

There is a short story by the US humorist Josh Billings in which a farmer discovers that his black horses are eating more hay than his white horses. Eventually he gets to the root of the matter and finds the explanation: he has more black horses than white. The confusion of mind that Ehrlich exposes to view is often close to that of Billings's farmer.

Here and there I found myself wondering whether, in striving for objectivity, Ehrlich was not putting too much weight on publications of uncertain authority in dubious journals. All the same, he has dug consistently deep and marshalled the evidence in masterly style. He is unfailingly lucid, and if his colloquial, rather jokey manner brings his book more readers, then so much the better, for the lessons that it teaches are important to us all. It upholds, moreover, the principle enunciated by an academic politician of legendary dexterity, a famous British vice-chancellor: one must always keep scientists away from committees - they are apt to change their minds in response to the evidence.

Walter Gratzer is emeritus professor of biophysical chemistry, King's College London, the Randall Centre, Guy's Campus, St Thomas' Street, London SE1 1UL, UK

\section{Birds and the double elephant}

\section{Audubon's Elephant: The Story of John James Audubon's Epic Struggle to Publish The Birds of America}

by Duff Hart-Davis

Weidenfeld \& Nicolson: 2003.192 pp. £18.99

(to be published in the US by Henry Holt next April)

\section{Audubon in Edinburgh: And his Scottish Associates \\ by John Chalmers \\ National Museums of Scotland: 2003. \\ 240 pp. $£ 30$}

\section{David Knight}

John James Audubon's enormous Birds of America books (1827-38) could not be printed and published in his native United States — the skills available to produce a book of this size were available only in Europe. So Audubon travelled to Britain,

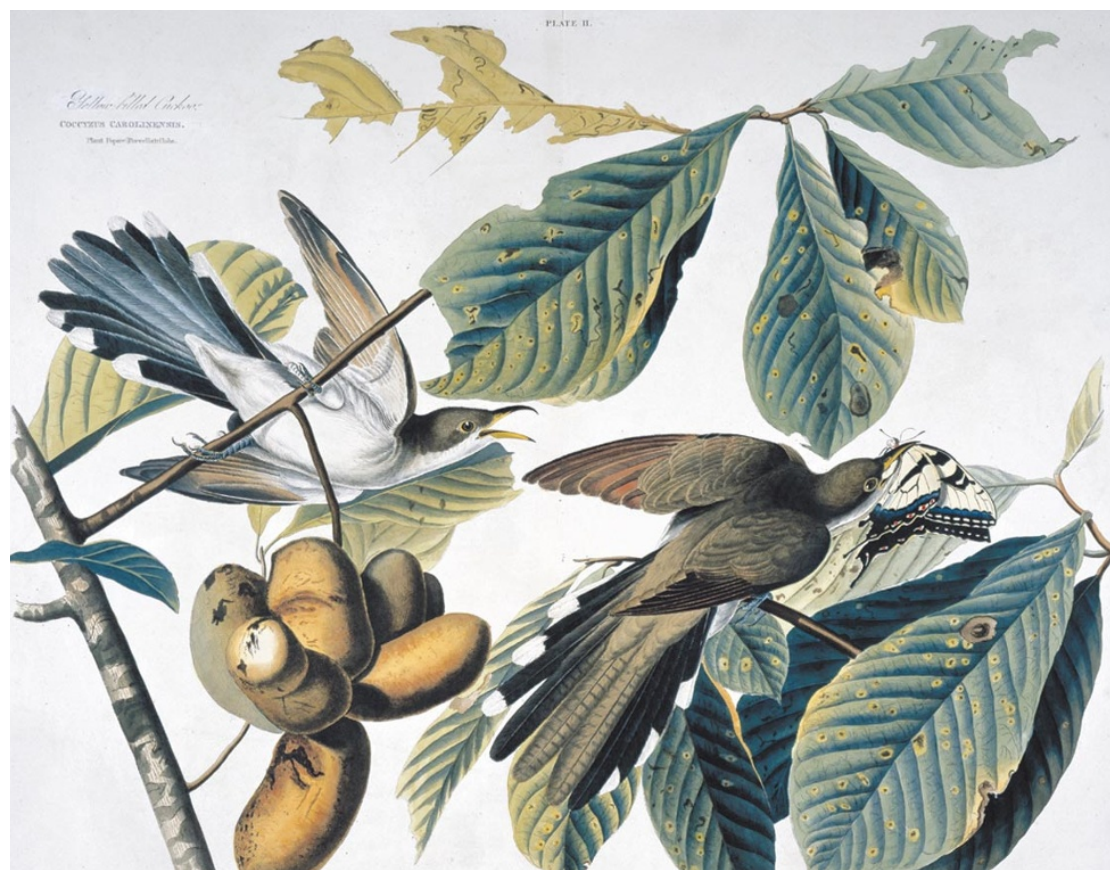

Huge undertaking: this yellow-billed cuckoo was life-sized in John James Audubon's Birds of America.

first to Liverpool and then on to Edinburgh, bringing with him his astonishing portfolio, which was big enough for all of the birds to be portrayed life-sized. Audubon in Edinburgh and Audubon's Elephant both focus on how the resulting extraordinary volumes of Birds of America, which now sell for millions of dollars, were produced. And they tell how Audubon recruited subscribers to fund the printing of successive volumes, a process that took more than a decade. It is a romantic story.

Audubon's volumes stand a metre tall the title of Hart-Davis's book refers to the size of the format, double elephant - and his work is marvellous, but is it science? Or is it, in fact, a white elephant? This question in part lay behind Audubon's rows with George Ord of the American Philosophical Society in Philadelphia and the eccentric traveller, squire and naturalist Charles Waterton in England, who considered him a charlatan. Clearly, Audubon was not that, even if his tales from the wild frontier about wildlife, ancestry and adventures improved in the telling. In line with the maxim "What's hit is history, but what's missed is mystery", Audubon slaughtered masses of his beloved birds in order to mount them convincingly and paint them.

Huge tomes sold in small editions are not the stuff of serious ornithology. This made Audubon's alliance with the Scottish naturalist William MacGillivray so important, although in print Audubon hardly seems to have done him justice. MacGillivray did the dissections and got the science right in the volumes of text, Ornithological Biography, that were published to accompany the plates. William Swainson had been in line for this job but had stuck out for fairer terms and broken off negotiations. Swainson was a leading illustrator and author of books on zoology, but his trinitarian (or quinarian) taxonomic system was coming to be seen as a speculative straitjacket on nature, and the book would have been poorer had it been saddled with it.

Audubon's life until 1826 had been a series of failures culminating in rows in Philadelphia where the memory of Alexander Wilson, his predecessor as America's leading ornithologist, was assiduously kept fresh. But despite his detractors, Audubon was elected to several scientific societies, including the Royal Society. The books by Hart-Davis and Chalmers both tell the tale of how this frontiersman, for whom English was a second language, managed to break into the scientific community through his energy, enthusiasm and sheer talent as a painter.

Finding friends and admirers in Liverpool, Audubon went to Edinburgh with more confidence. There he ignored advice to publish in a small format, and met William Lizars, who was to do some exquisite plates for William Jardine's series The Naturalist's Library. Lizars engraved and printed Audubon's plates and coloured them by hand - this was by necessity variable, and was a frequent source of complaint from the subscribers who sponsored the work. After producing a few of these, Lizars, faced with a strike and overstretched, was happy to give up.

Audubon, by then in London, found that Robert Havell and his son (also Robert) would do the job at a lower rate, and they ended up doing almost all of the plates. 